\title{
The Impact of Sampling Type, Frequency and Scale of Collection System on SARS- CoV-2 Quantification Fidelity
}

Andrea D. George ${ }^{1,2}$, Devrim Kaya ${ }^{2}$, Blythe A. Layton ${ }^{1}$, Kestrel Bailey ${ }^{1}$, Christine Kelly ${ }^{2}$, Kenneth J. Williamson ${ }^{1}$, Tyler S. Radniecki ${ }^{2 *}$

*Corresponding author: tyler.radniecki@oregonstate.edu

${ }^{1}$ Department of Research \& Innovation, Clean Water Services, Hillsboro, OR, 97123

${ }^{2}$ School of Chemical, Biological, and Environmental Engineering, Oregon State University, Corvallis, OR, 97331

\begin{abstract}
With the rapid onset of the COVID-19 pandemic, wastewater-based epidemiology (WBE) sampling methodologies for SARS-CoV-2 were often implemented quickly and may not have taken the unique drainage catchment characteristics into account. One question of debate is the relevance of grab versus composite samples when surveying for SARS-CoV-2 at various catchment scales. This study assessed the impact of grab versus composite sampling on the detection and quantification of SARS-CoV-2 in catchment basins with flow rates ranging from high-flow (wastewater treatment plant influent), to medium-flow (neighborhood-scale micro-sewershed), to low-flow (city block-scale micro-sewershed) and down to ultra-low flow (building scale). At the high-flow site, grab samples were reasonably comparable to 24-h composite samples with the same non-detect rate (0\%) and SARS-CoV-2 concentrations that differed by $32 \%$ on the $\log _{10}$ scale. However, as the flow rates decreased, the percentage of false-negative grab samples increased up to $44 \%$ and the SARS-CoV-2 concentrations of grab samples varied by up to 1-2 orders of magnitude compared to their respective composite sample concentrations. At the ultra-low-flow site, increased sampling frequencies down to every 5 min led to composite samples with higher fidelity to the SARS-CoV-2 load. Thus, composite sampling is superior to grab sampling, especially as flow decreases.
\end{abstract}

\section{Keywords}

Wastewater based epidemiology; SARS-CoV-2; composite sampling; grab sampling; collection basin scale; frequency; RT-ddPCR

\section{Synopsis}

The need for composite sampling to generate reliable SARS-CoV-2 wastewater based epidemiology results increases as the collection basin scale decreases. 
medRxiv preprint doi: https://doi.org/10.1101/2021.07.07.21260158; this version posted July 8, 2021. The copyright holder for this preprint (which was not certified by peer review) is the author/funder, who has granted medRxiv a license to display the preprint in perpetuity.

It is made available under a CC-BY-NC-ND 4.0 International license .

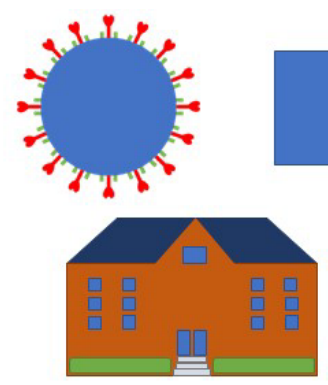

ULTRA-LOW-FLOW

\section{SARS-CoV-2 Sampling}
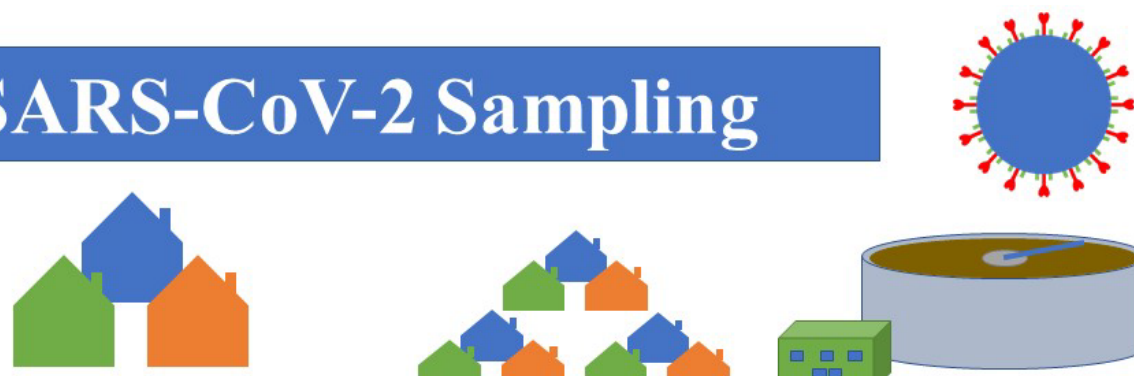

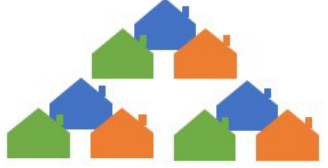

MEDIUM-FLOW

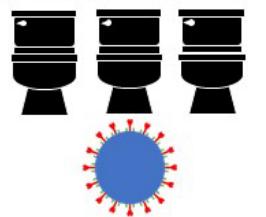

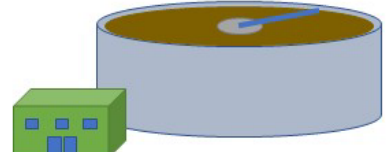

HIGH-FLOW
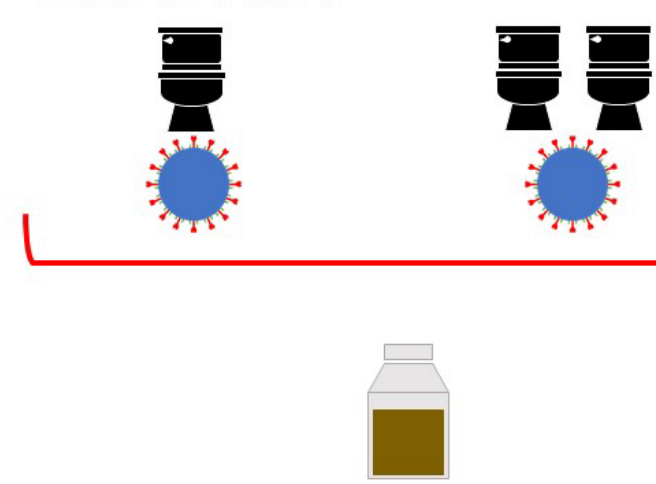

(1)

(1) (1)

GRAB
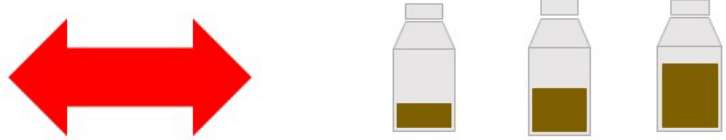

COMPOSITE

\section{Table of Content Art}


medRxiv preprint doi: https://doi.org/10.1101/2021.07.07.21260158; this version posted July 8, 2021. The copyright holder for this preprint (which was not certified by peer review) is the author/funder, who has granted medRxiv a license to display the preprint in perpetuity. It is made available under a CC-BY-NC-ND 4.0 International license .

\section{Introduction}

Since the start of the COVID-19 pandemic, wastewater-based epidemiology (WBE) has been widely used to track community SARS-CoV-2 viral burdens ${ }^{1}$. However, due to the temporal variability in SARS-CoV-2 loading into sewersheds, non-optimized sampling approaches in terms of type and/or frequency may introduce unintended biases. These include false negatives and gross over- or underestimation of total daily viral loads.

Two of the most common WBE sampling approaches are grab and composite sampling. Composite sampling has been used to improve detection given the uncertainty of shedding rates and fluctuations in diurnal wastewater flowrate ${ }^{1-5}$. A downside to composite sampling is that it requires investing in costly and cumbersome equipment (e.g. autosamplers). Thus, grab sampling has also been used to monitor for SARS-CoV-2 in wastewater treatment plant (WWTP) influents and low-flow sewers leaving buildings ${ }^{6}$.

While cheaper, faster, and less laborious than composite sampling, there are concerns surrounding the accuracy of grab sampling due to the discrete and variable nature of SARS-CoV-2 inputs into the catchment. Likewise, the 1-h sampling frequency for creating 24-h composites is an industry standard that was developed for monitoring large catchment basins where there is significant time and flow for the dispersion of a target signal. However, it is unclear if this sampling frequency is adequate to accurately capture SARS-CoV-2 signals at much lower flow rates closer to the input source where time and flow for dispersion is minimal.

This study identifies the impact of sampling type and frequency on SARS-CoV-2 detection and quantification in wastewater samples collected from several catchment scales, ranging from influent at a WWTP to a cluster of buildings on a college campus. This study also provides insight into the temporal variability of SARS-CoV-2 concentrations under various flow regimes and how that may impact the interpretation of results generated by the grab and composite sampling approaches commonly used in WBE.

\section{Materials and Methods}

\section{Sampling Process and Site Description}

Three sites with low-, medium-, and high-flow rates in the Forest Grove, Oregon sewershed were selected for $24 \mathrm{~h}$ sampling. The low-flow site $\left(0.42 \mathrm{~m}^{3} / \mathrm{min}\right.$ average dry weather flow) serves 400 people in a small residential community while also receiving industrial discharge from three food processing plants with $24 \mathrm{~h}$ operations. The medium-flow site $\left(2.65 \mathrm{~m}^{3} / \mathrm{min}\right.$ average dry weather flow $)$ receives most of its flow from a 2,200-person residential community with some small commercial businesses. The high-flow site $\left(9.20 \mathrm{~m}^{3} / \mathrm{min}\right.$ average dry weather flow) is the influent to the Forest Grove WWTP that serves approximately 40,000 residents and receives a mixture of industrial wastewater.

Hourly grab samples $(200 \mathrm{~mL})$ were taken from the low-, medium-, and high-flow sites with an icecooled 24-bottle ISCO 3700 autosampler (Teledyne ISCO, Lincoln, NE). Time-weighted composite samples were prepared by combining $10 \mathrm{~mL}$ of each hourly grab sample together. The SARS-CoV-2 concentrations for grab and time-weighted composite samples were quantified as described below. 
medRxiv preprint doi: https://doi.org/10.1101/2021.07.07.21260158; this version posted July 8, 2021. The copyright holder for this preprint (which was not certified by peer review) is the author/funder, who has granted medRxiv a license to display the preprint in perpetuity. It is made available under a CC-BY-NC-ND 4.0 International license .

The ultra-low-flow site served four college dormitory buildings, one of which was used to temporarily house COVID-19 infected students for convalescence. Grab samples (400 mL) were collected every 15 min for an $8 \mathrm{~h}$ period and every $5 \mathrm{~min}$ in the first $2 \mathrm{~h}$. Time-weighted composites were calculated $i n$ silico by averaging the SARS-CoV-2 concentrations of the grab samples.

\section{Sample Concentration}

Samples were stored at $-20^{\circ} \mathrm{C}$ for $1-50 \mathrm{~d}$ before concentration (Table S1). Frozen samples were thawed in a warm water bath $\left(\sim 30^{\circ} \mathrm{C}\right)$ and concentrated by filtering samples $(10-50 \mathrm{~mL}$, depending on suspended solid content) through an electronegative mixed cellulose ester membrane filter (Whatman catalog no. 7141-104, Buckinghamshire, UK). Following filtration, filters were placed into 2-mL tubes containing 0.7-mm garnet beads and $1 \mathrm{~mL}$ DNA/RNA Shield (Zymo Research, Irvine, CA) and stored at $-80{ }^{\circ} \mathrm{C}$ for $1-17$ days (mean: $6 \pm 4$ days) until RNA extraction.

\section{RNA Extraction}

All concentrated samples were thawed at room temperature $\left(\sim 20^{\circ} \mathrm{C}\right)$ and homogenized using a BioSpec Mini-Beadbeater 16 (BioSpec Products, Inc, Bartlesville, OK) for $2 \mathrm{~min}$. Samples were kept on ice during RNA extraction. The beads and debris were centrifuged at 12,000 rcf for $1 \mathrm{~min}$ to remove debris. Lysate was transferred from each tube to a 96-well plate. RNA was extracted from $200 \mu \mathrm{L}$ of lysate using the MagMAX Viral/Pathogen kit on a KingFisher automated instrument (ThermoFisher Scientific, Waltham, MA). Purified RNA was eluted in $30 \mu \mathrm{L}$ in elution buffer provided with the extraction kit. Positive SARS-CoV-2 controls containing the E, N, ORF1ab, RdRP, and S genes and human RNAse P RNA (EDX SARS-CoV-2 Standard, Exact Diagnostics, Fort Worth, TX) and negative controls containing certified SARS-CoV-2-free human RNAse P RNA (EDX SARS-CoV-2 Negative, Exact Diagnostics, Fort Worth, TX) were included in each extraction plate. Extraction blanks of phosphate buffered saline (PBS) were included with every run as an extraction contamination control. Reverse transcriptase droplet digital PCR (RT-ddPCR) immediately followed RNA extraction and purification.

\section{Reverse Transcriptase Digital Droplet PCR}

SARS-CoV-2 was quantified using a commercial triplex assay (2019-nCoV CDC ddPCR Triplex Probe Assay, Bio-Rad catalog no. 12008202) and the one-step RT-ddPCR Advanced Kit for Probes on the QX-200 ddPCR system (Bio-Rad, Hercules, CA). This assay uses the CDC's N1 and N2 primers with RNAse P included as an internal control. The primer and probe sequences were published previously ${ }^{7}$. An automated droplet generator generated the droplets (mean: 12,534 ( \pm 2114$)$ droplets per reaction). Duplicate analyses were performed for each sample and control. No template controls were included on each plate. The one-step thermal cycling conditions were as follows: reverse transcription at $50{ }^{\circ} \mathrm{C}$ for $60 \mathrm{~min}$; enzyme activation at $95^{\circ} \mathrm{C}$ for $10 \mathrm{~min}$; 40 cycles of denaturation at $94{ }^{\circ} \mathrm{C}$ for $30 \mathrm{~s}$ followed by annealing/extension at $55^{\circ} \mathrm{C}$ for $60 \mathrm{~s}$; enzyme inactivation at $98{ }^{\circ} \mathrm{C}$ for $10 \mathrm{~min}$; and lastly a $4{ }^{\circ} \mathrm{C}$ hold for droplet stabilization, for a minimum of $30 \mathrm{~min}$ to a maximum of overnight. Finally, the amplification in 
medRxiv preprint doi: https://doi.org/10.1101/2021.07.07.21260158; this version posted July 8, 2021. The copyright holder for this preprint (which was not certified by peer review) is the author/funder, who has granted medRxiv a license to display the preprint in perpetuity. It is made available under a CC-BY-NC-ND 4.0 International license .

the droplets was determined using the Bio-Rad droplet reader. All assay conditions were performed as specified in the Bio-Rad assay protocol ${ }^{8}$.

\section{Data Analysis}

The QuantaSoft Analysis Pro software (Bio-Rad, Hercules, CA) was used to manually call droplet clusters for each target. R (version 4.0.2) with Rstudio Desktop (version 1.3.1056) and Microsoft Excel was used for all other analysis, and graphics were created with Microsoft Excel and ggplot2 ${ }^{9}$. N1 and N2 concentrations showed good agreement and thus their geometric mean was used for all analyses (Figure S1).

\section{Quality Control and Error}

In data analysis, samples were only accepted if the corresponding extraction blank, field blank, negative control, and no-template control (NTC) were all negative for SARS-CoV-2 assays (i.e., N1 and N2) and $\mathrm{BCoV}$ (in process recovery experiment determined below). Reactions with less than 6,000 droplets were treated as failures and repeated. If the targets (i.e., N1 or N2 for SARS-CoV-2, and BCoV) were amplified in at least three droplets per reaction, the reaction was accepted as positive. Limit of detection (LOD) was determined empirically to be 8 copies per reaction for $\mathrm{N} 1$ and 12 copies per reaction for N2. The SARS-CoV-2 concentration of the sample was calculated using Equation 1 in Supporting Information and the values for each sample (i.e., four values for SARS-CoV-2: two for each N1 and N2 targets, or two values for bovine coronavirus $(\mathrm{BCoV})$ for duplicate samples) aggregated by a geometric mean. Non-detect values were replaced with half of the sample-specific limit of detection when calculating the mean. The sample-specific LOD was calculated from a conservative theoretical detection limit of 3 copies/reaction using Equation 1 in Supporting Information.

\section{Bovine coronavirus (BCoV) process recovery control}

Similar to other studies, an attenuated vaccine strain of $\mathrm{BCoV}$, was selected as a process recovery control due to its morphological and structural similarity to SARS-CoV-2 $2^{10,11}$. BCoV solution was prepared from freeze-dried Calf Guard cattle vaccine (Bovine Rotavirus-Coronavirus Vaccine from Zoetis, NJ, USA) as described in the Supplemental Information ${ }^{12}$.

To determine process recovery efficiency, $5 \mu \mathrm{L}$ of $\mathrm{BCoV}$ was added to $25 \mathrm{~mL}$ of wastewater (n=8) just prior to filtration. The $\mathrm{BCoV}$ recovery was calculated by dividing the quantity measured in wastewater samples to the quantity added to each wastewater sample prior to concentration. The mean $\mathrm{BCoV}$ recovery was $57( \pm 4) \%$. Non-spiked wastewater samples $(n=4)$ were also quantified for $\mathrm{BCoV}$ to assess background concentration. No $\mathrm{BCoV}$ was detected in non-spiked samples.

\section{Results and Discussion}


medRxiv preprint doi: https://doi.org/10.1101/2021.07.07.21260158; this version posted July 8, 2021. The copyright holder for this preprint (which was not certified by peer review) is the author/funder, who has granted medRxiv a license to display the preprint in perpetuity. It is made available under a CC-BY-NC-ND 4.0 International license .

\section{Effect of Sampling Type on Presence/Absence Detection of SARS-CoV-2}

One objective of WBE is to use the presence or absence of SARS-CoV-2 signal in a wastewater sample to indicate the presence or absence of COVID-19 in the community ${ }^{6,13}$. To determine how the sampling approach affects the reliability of presence/absence determination at different drainage basin scales, grab and composite samples (collected over the same sampling period) were collected from 4 catchments ranging in size from an entire sewershed with high flow down to a micro-sewershed encompassing a few buildings with ultra-low flow. At all four flows, SARS-CoV-2 was detected in the composites at concentrations above LOD. Additionally, all grab samples at the high flow site (i.e. the WWTP) yielded SARS-CoV-2 concentrations greater than LOD, similar to a recent study comparing composites collected over 1-h and 24-h at a WWTP ${ }^{2}$. However, as wastewater flow decreased, the percent occurrence of grab sample non-detects increased from $0 \%$ at the high flowrate up to $43.5 \%$ and $40.6 \%$ at the low flow and ultra-low flow locations, respectively (Table 1).

Since all four sites had positive composites, the increase in grab sample non-detects at lower flow sites located closer to the input source suggests that the SARS-CoV-2 signal did not have enough time to spread out via dispersion mechanisms. This is reflected in the difference of the maximum and minimum SARS-CoV-2 concentrations observed at each location. This value was highest at the ultra-low flow site (4.21 $\left.\log _{10} \mathrm{gc} / \mathrm{L}\right)$ and decreased consistently as the flow increased, down to $1.36 \log _{10} \mathrm{gc} / \mathrm{L}$ at the high flow site (Figure 1). These results indicate grab samples may be acceptable at high-flow sites (e.g. WWTP influent) for presence/absence analyses, although this may change if the SARS-CoV-2 load is low in the community ${ }^{2,14}$. However, at low-flow or ultra-low flow sites (e.g. individual buildings), where SARS-CoV-2 signals appear in short bursts, composite sampling provides the most reliable information regarding signal presence.

Table 1. Summary of results at different flow rates and sampling frequencies. Ultra-Low-Flow composite concentrations $(*)$ were calculated in silico from the corresponding grab samples. The UltraLow-Flow 15 min results $(* *)$ are shown twice for comparison purposes. MAE $=$ mean absolute error. $\mathrm{RMSLE}=$ root mean squared log error.

\begin{tabular}{|c|c|c|c|c|c|c|c|c|c|c|c|}
\hline Site & $\begin{array}{c}\text { Number } \\
\text { of Grab } \\
\text { Samples } \\
\text { (n) } \\
\end{array}$ & $\begin{array}{c}\text { Total } \\
\text { Sampling } \\
\text { Time } \\
\text { (h) } \\
\end{array}$ & $\begin{array}{c}\text { Avg Dry } \\
\text { Weather } \\
\text { Flowrate } \\
\text { (GPM) }\end{array}$ & $\begin{array}{l}\text { Sampling } \\
\text { Frequency }\end{array}$ & $\begin{array}{c}\text { Composite } \\
\text { Concentration } \\
\left(\log _{10} g c / L\right) \\
\end{array}$ & $\begin{array}{c}\text { Maximum } \\
\text { Grab } \\
\text { Concentration } \\
\left(\log _{10} \mathrm{gc} / \mathrm{L}\right) \\
\end{array}$ & $\begin{array}{c}\text { Minimum } \\
\text { Grab } \\
\text { Concentration } \\
\left(\log _{10} \mathrm{gc} / \mathbf{L}\right) \\
\end{array}$ & $\begin{array}{c}\text { Percent } \\
\text { Non- } \\
\text { Detects }\end{array}$ & $\begin{array}{c}\text { Percent } \\
\text { Grabs } \\
\text { Below } \\
\text { Composite } \\
\end{array}$ & MAE & RMSLE \\
\hline \multicolumn{12}{|c|}{ Complete time series data from all four catchment basins } \\
\hline Ultra-Low-Flow*: & 32 & 8 & - & $15 \mathrm{~min}$ & $5.81 \pm 0.10^{*}$ & $7.16 \pm 0.02$ & $2.95 \pm 0.00$ & $40.6 \%$ & $93.8 \%$ & 2.16 & 2.28 \\
\hline Low-Flow & 23 & 24 & 111 & $1 \mathrm{~h}$ & $4.77 \pm$ & $5.54 \pm 0.01$ & $3.18 \pm \quad 0.00$ & 43 & $78.3 \%$ & 1.01 & 1.04 \\
\hline Medium-Flow & 24 & 24 & 700 & $1 \mathrm{~h}$ & $3.74 \pm 0.24$ & $4.66 \pm 0.02$ & $3.05 \pm 0.00$ & $37.5 \%$ & $62.5 \%$ & 0.48 & 0.53 \\
\hline High-Flow & 24 & 24 & 2430 & $1 \mathrm{~h}$ & $3.94 \pm 0.13$ & $4.47 \pm \quad 0.04$ & $3.11 \pm \quad 0.16$ & $0.0 \%$ & $58.3 \%$ & 0.32 & 0.40 \\
\hline \multicolumn{12}{|c|}{ Data from the first $2 \mathrm{~h}$ of collection at the Ultra-Low Flow site at sampling frequencies of 5, 10 and $15 \mathrm{~min}$} \\
\hline Ultra-Low-Flow & 24 & 2 & - & $5 \mathrm{~min}$ & $5.88 \pm 0.11^{*}$ & $7.16 \pm 0.02$ & $3.05 \pm 0.00$ & $25.0 \%$ & $91.7 \%$ & 1.87 & 2.01 \\
\hline Ultra-Low-Flow & 12 & 2 & - & & & $7.16 \pm 0$. & $3.05 \pm 0$ & & & 6 & 2.21 \\
\hline Ultra-Low-Flow & 8 & 2 & - & $15 \mathrm{~min}$ & $6.26 \pm 0.22 *$ & $7.16 \pm \quad 0.02$ & $3.05 \pm \quad 0.00$ & $12.5 \%$ & $87.5 \%$ & 2.18 & 2.35 \\
\hline \multicolumn{12}{|c|}{ Data from the first $8 \mathrm{~h}$ of collection at the Ultra-Low Flow site at sampling frequencies of 15,30 and $60 \mathrm{~min}$} \\
\hline Ultra-Low-Flow*: & 32 & 8 & - & $15 \mathrm{~min}$ & $5.81 \pm 0.10^{*}$ & $7.16 \pm 0.02$ & $2.95 \pm \quad 0.00$ & $40.6 \%$ & $93.8 \%$ & 2.16 & 2.28 \\
\hline Ultra-Low-Flow & 17 & 8 & - & $30 \mathrm{~min}$ & $5.98 \pm 0.14^{*}$ & $7.16 \pm 0.02$ & $3.05 \pm \quad 0.00$ & $41.2 \%$ & $88.2 \%$ & 2.30 & 2.43 \\
\hline Ultra-Low-Flow & 9 & 8 & - & $1 \mathrm{~h}$ & $6.23 \pm 0.24 *$ & $7.16 \pm \quad 0.02$ & $3.05 \pm \quad 0.00$ & $33.3 \%$ & $88.9 \%$ & 2.52 & 2.65 \\
\hline
\end{tabular}


(a)

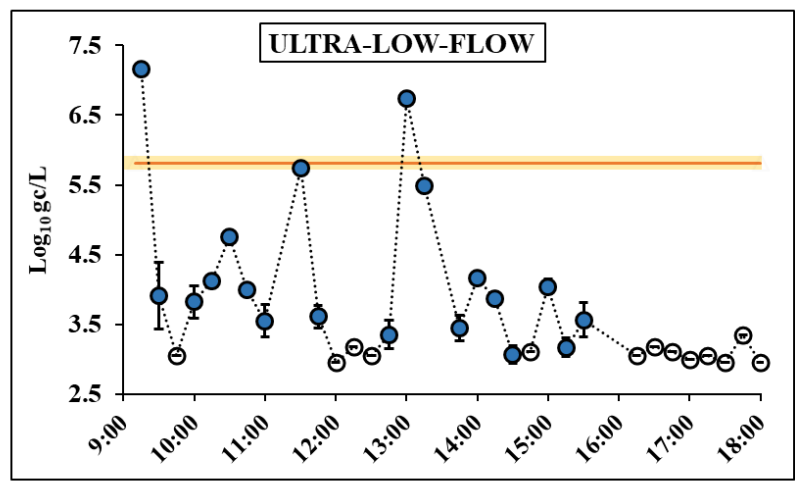

(c)

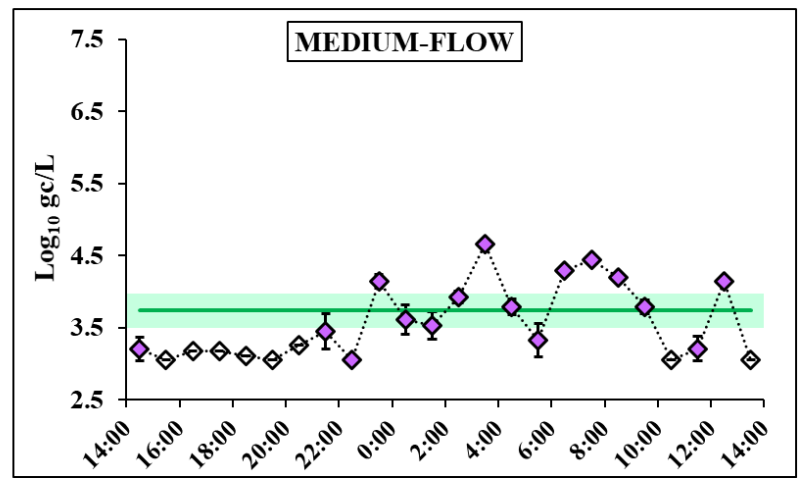

(b)

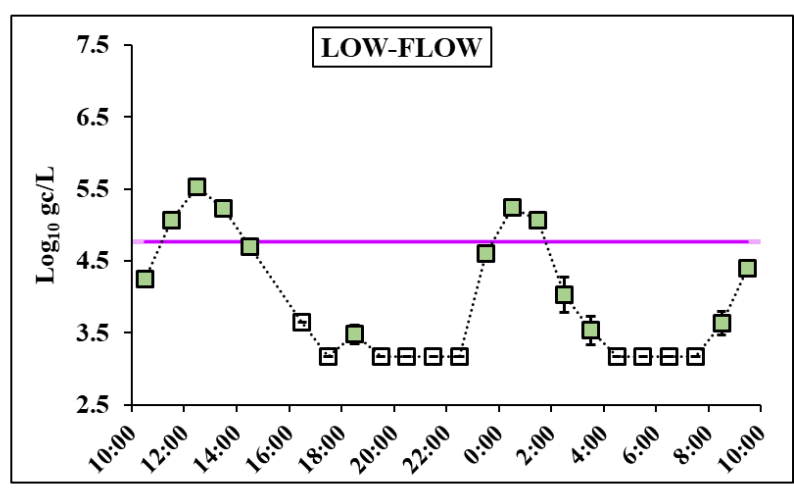

(d)

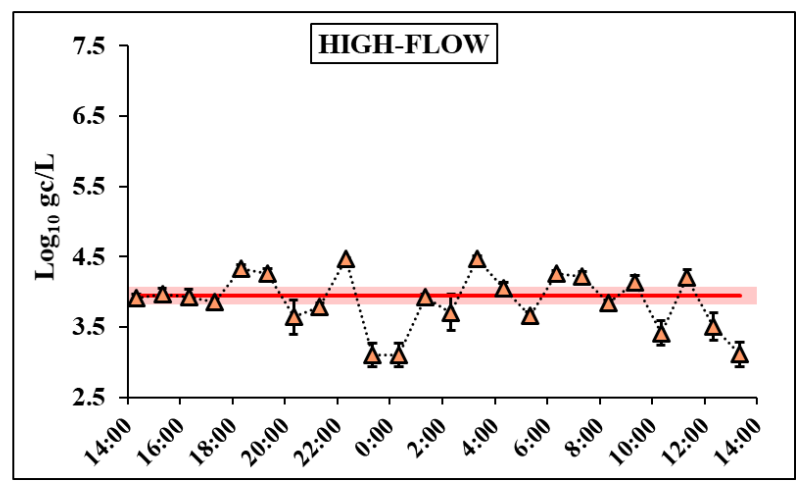

Figure 1. SARS-CoV-2 concentrations over time from grab samples collected from (a) ultra-low-flow (15-min sampling frequency), (b) low-flow, (c) medium-flow, and (d) high-flow sites. The solid line denotes the composite value for each time series. The error bars on the grab samples and the shaded range on the composite lines denote standard error. Non-detects are represented by open markers.

\section{Effect of Sampling Type on Quantification of SARS-CoV-2}

Wastewater SARS-CoV-2 concentrations have been used to indicate community COVID-19 levels and to predict case rate changes ${ }^{15,16}$. Two different error metrics were employed to determine the impact of sampling approaches on SARS-CoV-2 quantification at different drainage basin scales. The first, mean absolute error (MAE), quantifies the average discrepancy between the SARS-CoV-2 concentrations observed in the grab samples versus the composite sample at each site (Equation 2, Supporting Information). The second, root mean square log error (RMSLE), applies more weight to outliers than the MAE, while also penalizing grab samples with concentrations below the composite value more than those above it (Equation 3, Supporting Information) $)^{17,18}$.

With both error metrics, the highest relative error between the grab samples and their respective composites was present at the ultra-low-flow site with MAE and RMSLE values of 2.16 and 2.28, respectively (Table 1). As the flow of the site increased, the difference between the grab and composite sample concentrations decreased, with the high-flow site having MAE and RMSLE values of 0.32 and 
medRxiv preprint doi: https://doi.org/10.1101/2021.07.07.21260158; this version posted July 8, 2021. The copyright holder for this preprint (which was not certified by peer review) is the author/funder, who has granted medRxiv a license to display the preprint in perpetuity. It is made available under a CC-BY-NC-ND 4.0 International license .

0.40 , respectively. Thus, as the flow of the site increased, the relative error decreased and the grab samples became more representative of the composite value (Figure S2).

A recent study found that copies of SARS-CoV-2/100 mL of grab samples collected every $2 \mathrm{~h}$ from a WWTP influent were often within 50\% of their respective 24-h flow-weighted composite copies/100 $\mathrm{mL}$ values ${ }^{19}$. Similar results were observed in the present study, with the high flow grab sample SARSCoV-2 concentrations differing from their 24-h time-weighted composite concentration by an average of $32-40 \%$ of the $\log$ transformed value. Additionally, the grab sample SARS-CoV-2 concentrations at the high flow site were fairly well-distributed around the composite sample concentrations, with just over half $(58.3 \%)$ of the grab sample values falling below the composite sample values.

However, this outcome was not exhibited at the other three sites with lower flow. Grab sample SARSCoV-2 concentrations differed from their time-weighted composite sample values by around 1-2 orders of magnitude at the low-flow and ultra-low-flow site. Additionally, the distribution of the grab sample values around the composite sample concentrations was no longer approximately symmetrical (Figure 1). At the low-flow and ultra-low-flow sites, $78-94 \%$ of the grab sample concentrations were below the composite sample SARS-CoV-2 concentration (Table 1).

These results indicate that while grab samples may provide fairly representative SARS-CoV-2 concentrations at high flow sites (e.g. a WWTP influent), they fail to provide representative SARS-CoV2 concentrations at lower flow sites (e.g. buildings) and may lead to over- or under-estimates of viral burden. This high level of variability at lower flow sites closer to the input source is indicative of limited SARS-CoV-2 dispersion by that point in the conveyance system, and highlights the need for composite sampling at such locations.

\section{Effect of Sampling Frequency on Quantification of SARS-CoV-2}

The industry standard for creating 24-h time-weighted wastewater composites is to collect samples every hour, while recent studies have used a higher sampling frequency, ranging from 10 to $30 \mathrm{~min}$, to monitor building-scale catchments ${ }^{13,20}$. Given the high variability of SARS-CoV-2 concentrations at the ultra-low-flow site (Figure 1a), questions arise regarding the optimal sampling frequency for buildingscale catchments. To help answer these, the sampling frequency at the ultra-low-flow site was increased to every $5 \mathrm{~min}$ for the first $2 \mathrm{~h}$ (Figure S3) followed by a $15 \mathrm{~min}$ sampling frequency for the next $6 \mathrm{~h}$ of collection (Figure 1a).

For error metric analyses of sampling frequency over the first $2 \mathrm{~h}$, the $5 \mathrm{~min}$ grab sample SARS-CoV-2 concentrations were used as the standard that all three sampling frequencies $(5,10$, and $15 \mathrm{~min})$ composite SARS-CoV-2 concentrations were compared against (Figure S4). This was done under the assumption that the $5 \mathrm{~min}$ grab samples are as close to continuous sampling as could be reasonably obtained and therefore would provide the most accurate reflection of the SARS-CoV-2 load during that time. Likewise, for error metric analyses for sampling frequency over the entire $8 \mathrm{~h}$, the $15 \mathrm{~min}$ grab sample SARS-CoV-2 concentrations were used as the standard that the 15, 30, and 60 min sampling frequency composite SARS-CoV-2 concentrations were compared against (Figure S5). 
medRxiv preprint doi: https://doi.org/10.1101/2021.07.07.21260158; this version posted July 8, 2021. The copyright holder for this preprint (which was not certified by peer review) is the author/funder, who has granted medRxiv a license to display the preprint in perpetuity.

It is made available under a CC-BY-NC-ND 4.0 International license .

For both time ranges ( $2 \mathrm{~h}$ and $8 \mathrm{~h}$ ), the MAE and RMSLE increased with decreasing sampling frequency, with the highest values obtained from the composites from hourly sampling (Table 1). This demonstrates that reduced sampling frequency can result in the composite sample capturing less of the temporal variation of SARS-CoV-2 loads and reduces the accuracy of the composite sample's SARS$\mathrm{CoV}-2$ concentration. Thus, at ultra-low-flow sites, it is advisable to increase the sampling frequencies to the greatest extent practical.

\section{Recommendations for Sampling Plan Design}

Multiple factors should be considered in selecting the site-specific sampling method to optimize data collection. Among those factors, the scale of the catchment appears to strongly influence the sampling plan design by increasing the need for composite sampling at lower scales of flow. Additionally, the sampling frequency should also be considered, with special efforts to increase frequency at the individual building/campus level. Neither of these factors exist outside monetary and equipment restrictions; therefore, consideration should be given to the type of information desired to be obtained from the sampling (e.g., presence/absence versus quantitative viral concentrations) for better utilization and interpretation of the results.

\section{Abbreviations}

BCoV: Bovine Corona Virus

LOD: Limit of Detection

MAE: Mean Average Error

NTC: No Template Control

rcf: Relative Centrifugal Field

RMSLE: Root Mean Squared Log Error

RT-ddPCR: Reverse Transcription Droplet Digital Polymerase Chain Reaction

WBE: Wastewater-based Epidemiology

WWTP: Wastewater Treatment Plant

\section{Acknowledgements}

This work was supported by the National Science Foundation RAPID \#2027679. Clean Water Services participated in this research with partial funding from the CARES Act through the Washington County Cities and Special District Assistance program. We wish to acknowledge the assistance with sampling from Scott Mansell, Jason Cook and Jacob DeMartino of Clean Water Services. 
medRxiv preprint doi: https://doi.org/10.1101/2021.07.07.21260158; this version posted July 8, 2021. The copyright holder for this preprint (which was not certified by peer review) is the author/funder, who has granted medRxiv a license to display the preprint in perpetuity. It is made available under a CC-BY-NC-ND 4.0 International license .

\section{References}

(1) Ahmed, W.; Angel, N.; Edson, J.; Bibby, K.; Bivins, A.; O’Brien, J. W.; Choi, P. M.; Kitajima, M.; Simpson, S. L.; Li, J.; Tscharke, B.; Verhagen, R.; Smith, W. J. M.; Zaugg, J.; Dierens, L.; Hugenholtz, P.; Thomas, K. V.; Mueller, J. F. First Confirmed Detection of SARS-CoV-2 in Untreated Wastewater in Australia: A Proof of Concept for the Wastewater Surveillance of COVID-19 in the Community. Sci. Total Environ. 2020, 728, 138764. https://doi.org/10.1016/j.scitotenv.2020.138764.

(2) Ahmed, W.; Bivins, A.; Bertsch, P. M.; Bibby, K.; Gyawali, P.; Sherchan, S. P.; Simpson, S. L.; Thomas, K. V.; Verhagen, R.; Kitajima, M.; Mueller, J. F.; Korajkic, A. Intraday Variability of Indicator and Pathogenic Viruses in 1-h and 24-h Composite Wastewater Samples: Implications for Wastewater-Based Epidemiology. Environ. Res. 2020, 110531. https://doi.org/10.1016/j.envres.2020.110531.

(3) Peccia, J.; Zulli, A.; Brackney, D. E.; Grubaugh, N. D.; Kaplan, E. H.; Casanovas-Massana, A.; Ko, A. I.; Malik, A. A.; Wang, D.; Wang, M.; Warren, J. L.; Weinberger, D. M.; Arnold, W.; Omer, S. B. Measurement of SARS-CoV-2 RNA in Wastewater Tracks Community Infection Dynamics. Nat. Biotechnol. 2020, 38 (10), 1164-1167. https://doi.org/10.1038/s41587-020-0684$\mathrm{z}$.

(4) Lodder, W.; de Roda Husman, A. M. SARS-CoV-2 in Wastewater: Potential Health Risk, but Also Data Source. Lancet Gastroenterol. Hepatol. 2020, 5 (6), 533-534. https://doi.org/10.1016/S2468-1253(20)30087-X.

(5) Wu, F.; Xiao, A.; Zhang, J.; Moniz, K.; Endo, N.; Armas, F.; Bonneau, R.; Brown, M. A.; Bushman, M.; Chai, P. R.; Duvallet, C.; Erickson, T. B.; Foppe, K.; Ghaeli, N.; Gu, X.; Hanage, W. P.; Huang, K. H.; Lee, W. L.; Matus, M.; McElroy, K. A.; Nagler, J.; Rhode, S. F.; Santillana, M.; Tucker, J. A.; Wuertz, S.; Zhao, S.; Thompson, J.; Alm, E. J. SARS-CoV-2 Titers in Wastewater Foreshadow Dynamics and Clinical Presentation of New COVID-19 Cases. medRxiv 2020, 2020.06.15.20117747. https://doi.org/10.1101/2020.06.15.20117747.

(6) Betancourt, W. Q.; Schmitz, B. W.; Innes, G. K.; Prasek, S. M.; Pogreba Brown, K. M.; Stark, E. R.; Foster, A. R.; Sprissler, R. S.; Harris, D. T.; Sherchan, S. P.; Gerba, C. P.; Pepper, I. L. COVID-19 Containment on a College Campus via Wastewater-Based Epidemiology, Targeted Clinical Testing and an Intervention. Sci. Total Environ. 2021, 779, 146408. https://doi.org/10.1016/J.SCITOTENV.2021.146408.

(7) Lu, X.; Wang, L.; Sakthivel, S. K.; Whitaker, B.; Murray, J.; Kamili, S.; Lynch, B.; Malapati, L.; Burke, S. A.; Harcourt, J.; Tamin, A.; Thornburg, N. J.; Villanueva, J. M.; Lindstrom, S. US CDC Real-Time Reverse Transcription PCR Panel for Detection of Severe Acute Respiratory Syndrome Coronavirus 2. Emerg. Infect. Dis. 2020, 26 (8), 1654-1665. https://doi.org/10.3201/eid2608.201246.

(8) Bio-Rad SARS-CoV-2 DdPCR Kit: Instructions for Use; 2020.

(9) Wickham, H. Ggplot2: Elegant Graphics for Data Analysis; Springer-Verlag: New York, 2016.

(10) Graham, K. E.; Loeb, S. K.; Wolfe, M. K.; Catoe, D.; Sinnott-Armstrong, N.; Kim, S.; Yamahara, K. M.; Sassoubre, L. M.; Mendoza Grijalva, L. M.; Roldan-Hernandez, L.; Langenfeld, K.; 
medRxiv preprint doi: https://doi.org/10.1101/2021.07.07.21260158; this version posted July 8, 2021. The copyright holder for this preprint (which was not certified by peer review) is the author/funder, who has granted medRxiv a license to display the preprint in perpetuity. It is made available under a CC-BY-NC-ND 4.0 International license .

Wigginton, K. R.; Boehm, A. B. SARS-CoV-2 RNA in Wastewater Settled Solids Is Associated with COVID-19 Cases in a Large Urban Sewershed. Environ. Sci. Technol. 2021, 55 (1), 488498. https://doi.org/10.1021/acs.est.0c06191.

(11) Pecson, B. M.; Darby, E.; Haas, C. N.; Amha, Y. M.; Bartolo, M.; Danielson, R.; Dearborn, Y.; Di Giovanni, G.; Ferguson, C.; Fevig, S.; Gaddis, E.; Gray, D.; Lukasik, G.; Mull, B.; Olivas, L.; Olivieri, A.; Qu, Y.; SARS-Cov-2 Interlaboratory Consortium. Reproducibility and Sensitivity of 36 Methods to Quantify the SARS-CoV-2 Genetic Signal in Raw Wastewater: Findings from an Interlaboratory Methods Evaluation in the U.S. Environ. Sci. Water Res. Technol. 2021, 7 (3), 504-520. https://doi.org/10.1039/d0ew00946f.

(12) Decaro, N.; Elia, G.; Campolo, M.; Desario, C.; Mari, V.; Radogna, A.; Colaianni, M. L.; Cirone, F.; Tempesta, M.; Buonavoglia, C. Detection of Bovine Coronavirus Using a TaqMan-Based Real-Time RT-PCR Assay. J. Virol. Methods 2008, 151 (2), 167-171. https://doi.org/10.1016/j.jviromet.2008.05.016.

(13) Gibas, C.; Lambirth, K.; Mittal, N.; Juel, M. A. I.; Barua, V. B.; Roppolo Brazell, L.; Hinton, K.; Lontai, J.; Stark, N.; Young, I.; Quach, C.; Russ, M.; Kauer, J.; Nicolosi, B.; Chen, D.; Akella, S.; Tang, W.; Schlueter, J.; Munir, M. Implementing Building-Level SARS-CoV-2 Wastewater Surveillance on a University Campus. Sci. Total Environ. 2021, 782, 146749. https://doi.org/10.1016/J.SCITOTENV.2021.146749.

(14) Gerrity, D.; Papp, K.; Stoker, M.; Sims, A.; Frehner, W. Early-Pandemic Wastewater Surveillance of SARS-CoV-2 in Southern Nevada: Methodology, Occurrence, and Incidence/Prevalence Considerations. Water Res. X 2021, 10, 100086. https://doi.org/10.1016/J.WROA.2020.100086.

(15) Daughton, C. G. Wastewater Surveillance for Population-Wide Covid-19: The Present and Future. Sci. Total Environ. 2020, 736, 139631. https://doi.org/10.1016/J.SCITOTENV.2020.139631.

(16) Agrawal, S.; Orschler, L.; Lackner, S. Metatranscriptomic Analysis Reveals SARS-CoV-2 Mutations in Wastewater of the Frankfurt Metropolitan Area in Southern Germany. Microbiol. Resour. Announc. 2021, 10 (15). https://doi.org/10.1128/MRA.00280-21.

(17) Chai, T.; Draxler, R. R. Root Mean Square Error (RMSE) or Mean Absolute Error (MAE)? Arguments against Avoiding RMSE in the Literature. Geosci. Model Dev. 2014, 7 (3), 12471250. https://doi.org/10.5194/GMD-7-1247-2014.

(18) Jeong, J. H.; Woo, J. H.; Park, J. G. Machine Learning Methodology for Management of Shipbuilding Master Data. Int. J. Nav. Archit. Ocean Eng. 2020, 12, 428-439. https://doi.org/10.1016/J.IJNAOE.2020.03.005.

(19) Curtis, K.; Keeling, D.; Yetka, K.; Larson, A.; Gonzalez, R. Wastewater SARS-CoV-2 Concentration and Loading Variability from Grab and 24-1 Hour Composite Samples. medRxiv 2020, 2020.07.10.20150607. https://doi.org/10.1101/2020.07.10.20150607.

(20) Colosi, L. M.; Barry, K. E.; Kotay, S. M.; Porter, M. D.; Poulter, M. D.; Ratliff, C.; Simmons, W.; Steinberg, L. I.; Wilson, D. D.; Morse, R.; Zmick, P.; Mathers, A. J. Development of Wastewater Pooled Surveillance of Severe Acute Respiratory Syndrome Coronavirus 2 (SARSCoV-2) from Congregate Living Settings. Appl. Environ. Microbiol. 2021, 87 (13), 433-454. 
medRxiv preprint doi: https://doi.org/10.1101/2021.07.07.21260158; this version posted July 8, 2021. The copyright holder for this preprint (which was not certified by peer review) is the author/funder, who has granted medRxiv a license to display the preprint in perpetuity.

https://doi.org/10.1128/AEM.00433-21.

\section{Disclosures}

The authors declare no competing financial interest.

\section{Supporting Information}

Figure S1. The N1 target concentrations ( $\log _{10}$ copies per reaction) plotted against the N2 target concentration ( $\log _{10}$ copies per reaction) in each reaction $(n=1,328)$ in every plate containing samples used in this study. Non-detects were replaced with 2 copies per reaction.

Figure S2. The boxplot exhibiting the distribution of viral concentrations ( $\log _{10}$ gene copies/liter) of the grab samples at ultra-low- (campus site), low-, medium-, and high-flow sites. The size of the box has a negative correlation with flowrate. The interquartile range (IQR) decreases with increasing flow except at the ultra-low-flow site with the 15-minute sampling frequency (ultra-low-flow $=0.9$, lowflow $=1.5 \log$ units, medium-flow=0.8 and the high-flow=0.5).

Figure S3. Variation in SARS-CoV-2 concentrations ( $\log _{10}$ gene copies per liter, gc/L) over time in grab samples collected from the ultra-low-flow site over 5 min intervals in the first $2 \mathrm{~h}$. The composite sample for the campus site was created digitally using the respective grab samples collected at 5 min intervals. The error bars on the grab samples and the shaded range on the composite lines denote standard error. Non-detects are represented by open markers.

Figure S4. The 5-min grab samples collected in the first $2 \mathrm{~h}$ of sample collection plotted with a solid line indicating the (a) 5-min sampling frequency composite, (b) 10-min sampling frequency composite, and (c) 15-min sampling frequency composite. The error bars on the grab samples and the shaded range on the composite lines denote standard error. Non-detects are represented by open markers.

Figure S5. The 15-min grab samples collected in $8 \mathrm{~h}$ of sample collection plotted with a solid line indicating the (a) 15-min sampling frequency composite, (b) 30-min sampling frequency composite, and (c) 1-h sampling frequency composite. The error bars on the grab samples and the shaded range on the composite lines denote standard error. Non-detects are represented by open markers.

Table S1. The storage time, temperature, and volume concentrated for each of the raw wastewater samples collected from the four sites. 


\section{Supporting Information}

\section{The Impact of Sampling Type, Frequency and Scale of Collection System on SARS- CoV-2 Quantification Fidelity}

Andrea D. George ${ }^{1,2}$, Devrim Kaya ${ }^{2}$, Blythe A. Layton ${ }^{1}$, Kestrel Bailey ${ }^{1}$, Christine Kelly ${ }^{2}$, Kenneth J. Williamson ${ }^{1}$, Tyler S. Radniecki ${ }^{*}$

${ }^{*}$ Corresponding author: tyler.radniecki@oregonstate.edu

${ }^{1}$ Department of Research \& Innovation, Clean Water Services, Hillsboro, OR, 97123

${ }^{2}$ School of Chemical, Biological, and Environmental Engineering, Oregon State University, Corvallis, OR, 97331

10 pages

3 Equations

5 Figures

1 Table 


\section{Equation S1. Conversion of copies/reaction to copies/L}

$$
\begin{aligned}
\frac{\text { copies }}{\text { rxn }} * \frac{1 \text { rxn }}{\text { Template Volume }(\mu L)} * \text { Elution Volume }(\mu L) * \frac{1}{\text { Lysate Volume }(\mu L)} \\
* \text { Shield Volume }(\mu L) * \frac{1}{\text { Volume Filtered }(m L)} * 1000 \frac{\mathrm{mL}}{\mathrm{L}}=\frac{\text { copies }}{\mathrm{L}}
\end{aligned}
$$

\section{Equation S2. Mean Absolute Error (MAE)}

$$
\frac{\sum_{i=1}^{n}\left|\widehat{y}_{l}-y_{i}\right|}{n}
$$

Where $\widehat{y}_{l}=$ observed value (log-transformed)

$$
\begin{aligned}
& y_{i}=\text { expected value (log-transformed) } \\
& n=\text { number of observations }
\end{aligned}
$$

Please note that the interpretation of the MAE requires the recognition of the use of log-transformed values. The log-transformation of the concentration establishes the metric as one of relative rather than absolute error (as the name may suggest), since log rules dictate that there is a division of the grab by the composite within the MAE calculation. Thus, the resulting MAE is a percent error not an absolute error.

\section{Equation S3. Root Mean Square Log Error (RMSLE)}

$$
\sqrt{\sum_{i=1}^{n} \frac{\left(\widehat{y}_{l}-y_{i}\right)^{2}}{n}}
$$

Where $\widehat{y}_{l}=$ observed value (log-transformed)

$$
\begin{aligned}
& y_{i}=\text { expected value (log-transformed) } \\
& n=\text { number of observations }
\end{aligned}
$$

Please note that the interpretation of the RMSLE requires the recognition of the use of log-transformed values. The log-transformation of the concentration establishes the metric as one of relative rather than 
medRxiv preprint doi: https://doi.org/10.1101/2021.07.07.21260158; this version posted July 8, 2021. The copyright holder for this preprint (which was not certified by peer review) is the author/funder, who has granted medRxiv a license to display the preprint in perpetuity.

It is made available under a CC-BY-NC-ND 4.0 International license .

absolute error (as the name may suggest), since log rules dictate that there is a division of the grab by the composite within the RMSLE calculation. Thus, the resulting RMSLE is a percent error not an absolute error.

\section{Bovine coronavirus (BCoV) stock solution preparation}

$\mathrm{BCoV}$ solution was prepared from freeze-dried Calf Guard cattle vaccine (Bovine RotavirusCoronavirus Vaccine from Zoetis, NJ, USA) after rehydrating in $3 \mathrm{~mL}$ of sterile diluent provided with the vaccine. Aliquots $(100 \mu \mathrm{L})$ of stock solution were stored at $-20^{\circ} \mathrm{C}$. Each aliquot was used for a maximum of two freeze-thaw cycles. To determine the stock concentration, $10 \mu \mathrm{L}$ BCoV stock was added to $390 \mu \mathrm{L}$ PBS. From this mixture, $200 \mu \mathrm{L}$ were extracted as described above. The extracted BCoV RNA was serially diluted (1:10) in nuclease-free water for six dilutions and run in duplicate using a previously published BCoV assay by following the one-step RT-ddPCR procedure as described in the text $^{12}$. Stock concentration of $\mathrm{BCoV}$ was around $2.3 \times 106 \mathrm{gc} / \mu \mathrm{L}$.

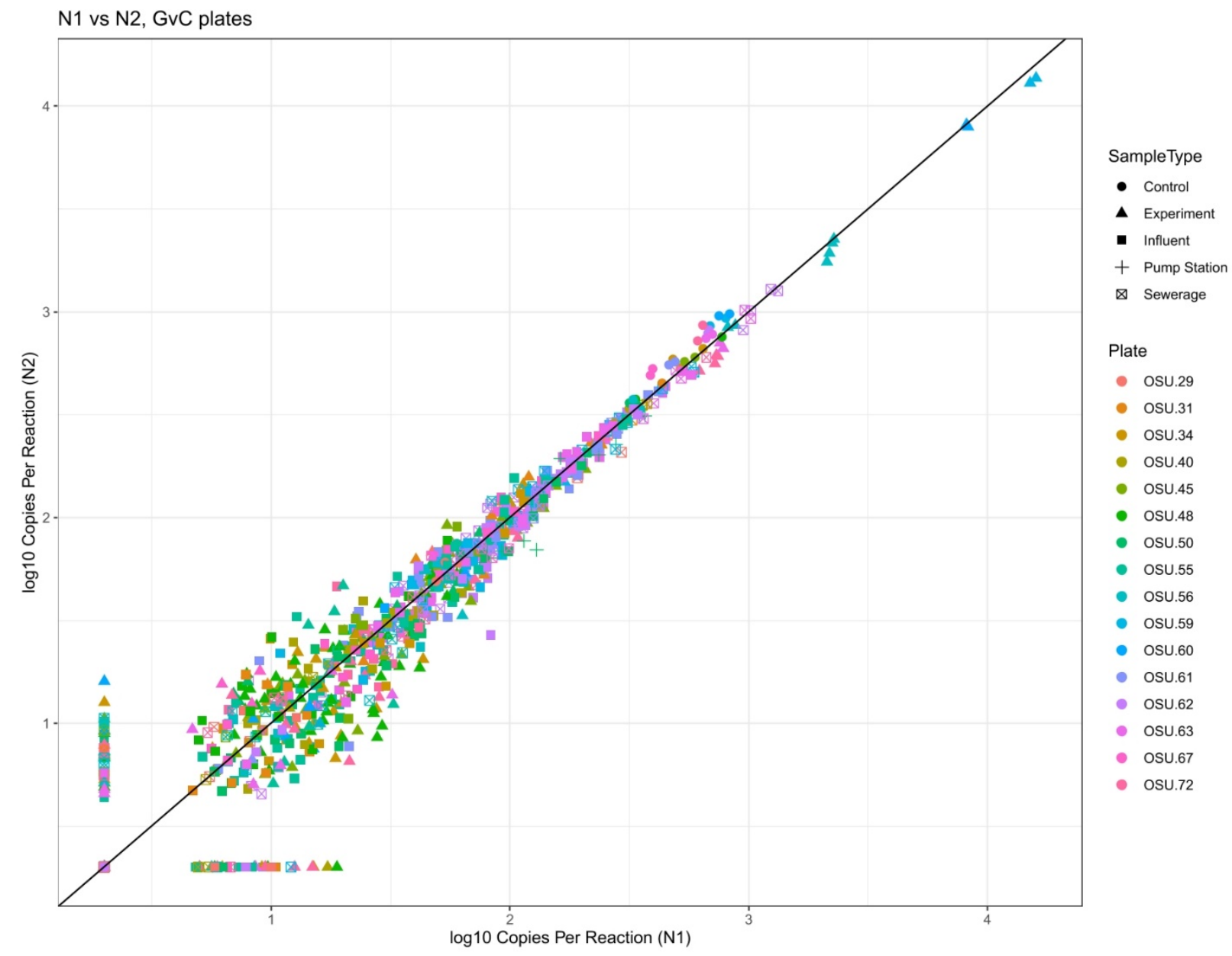

Figure S1. The N1 target concentrations ( $\log _{10}$ copies per reaction) plotted against the N2 target concentration ( $\log _{10}$ copies per reaction) in each reaction $(n=1,328)$ in every plate containing samples utilized in this study. Non-detects were replaced with 3 copies per reaction. 
medRxiv preprint doi: https://doi.org/10.1101/2021.07.07.21260158; this version posted July 8, 2021. The copyright holder for this preprint (which was not certified by peer review) is the author/funder, who has granted medRxiv a license to display the preprint in perpetuity.

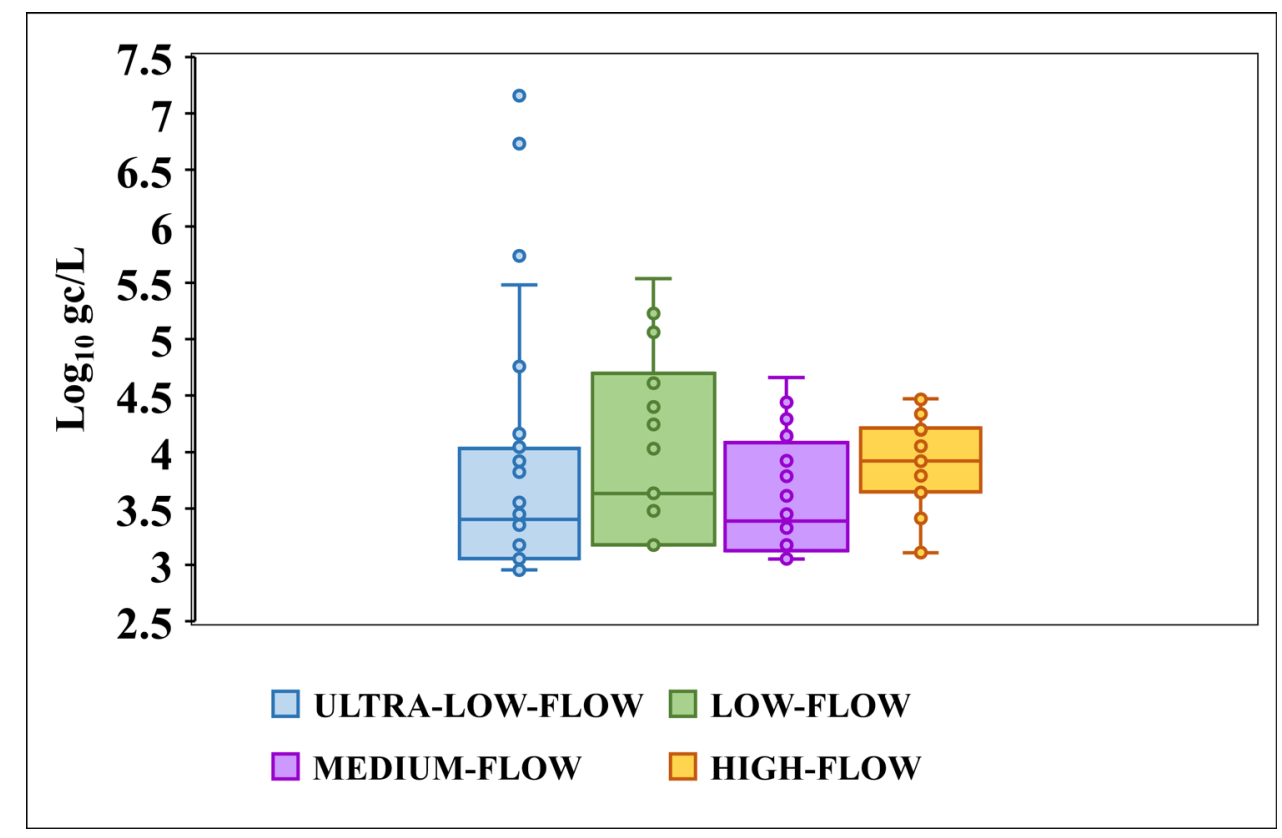

Figure S2. The boxplot exhibiting the distribution of viral concentrations ( $\log _{10}$ gene copies/liter) of the grab samples at ultra-low-, low-, medium-, and high-flow sites. The size of the box has a negative correlation with flowrate. The interquartile range (IQR) decreases with increasing flow except at the ultra-low-flow site with the 15-minute sampling frequency (ultra-low-flow $=0.9$, low-flow $=1.5 \log$ units, medium-flow $=0.8$ and the high-flow $=0.5$ ).

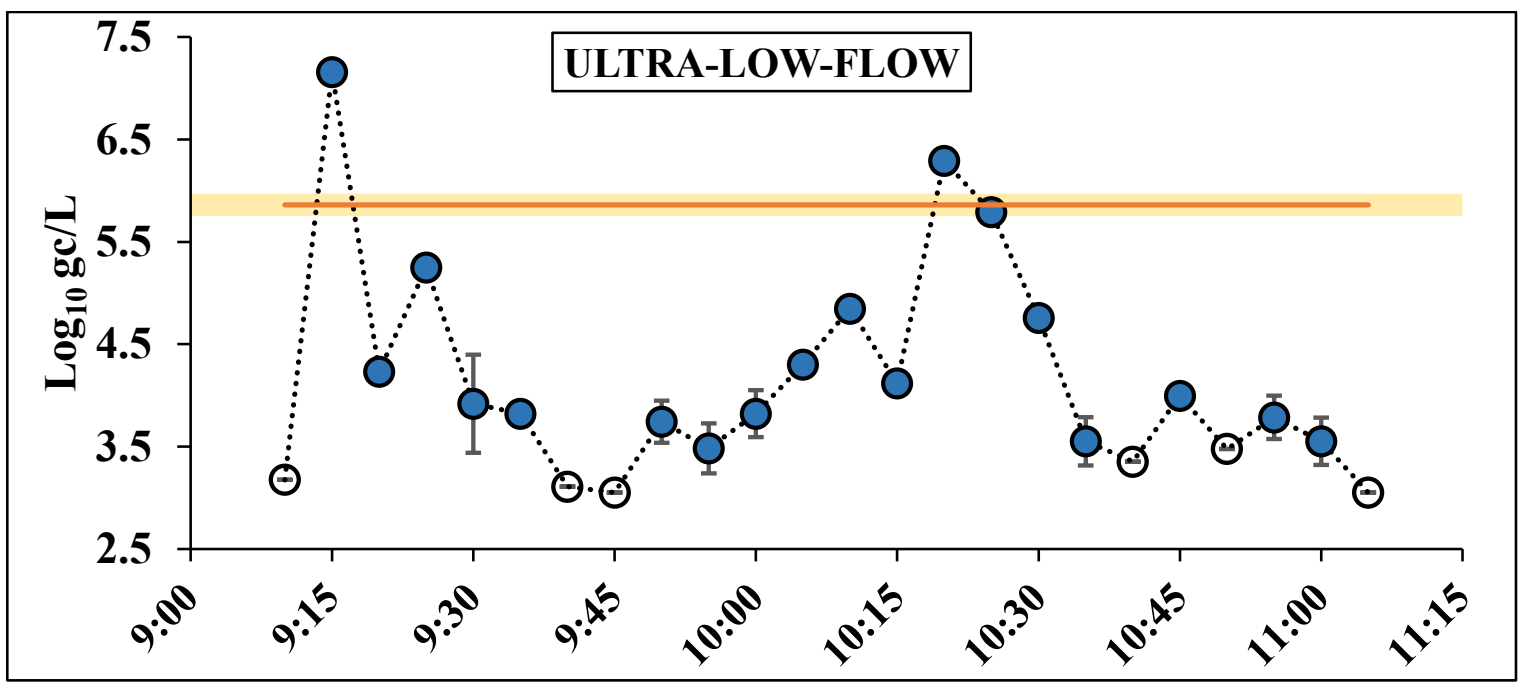

Figure S3. Variation in SARS-CoV-2 concentrations $\left(\log _{10}\right.$ gene copies per liter, gc/L) over time in grab samples collected from the ultra-low-flow site over 5 min intervals in the first $2 \mathrm{~h}$. The composite sample for the campus site was created digitally using the respective grab samples collected at 5 min intervals. The error bars on the grab samples and the shaded range on the composite lines denote standard error. Non-detects are represented by open markers. 


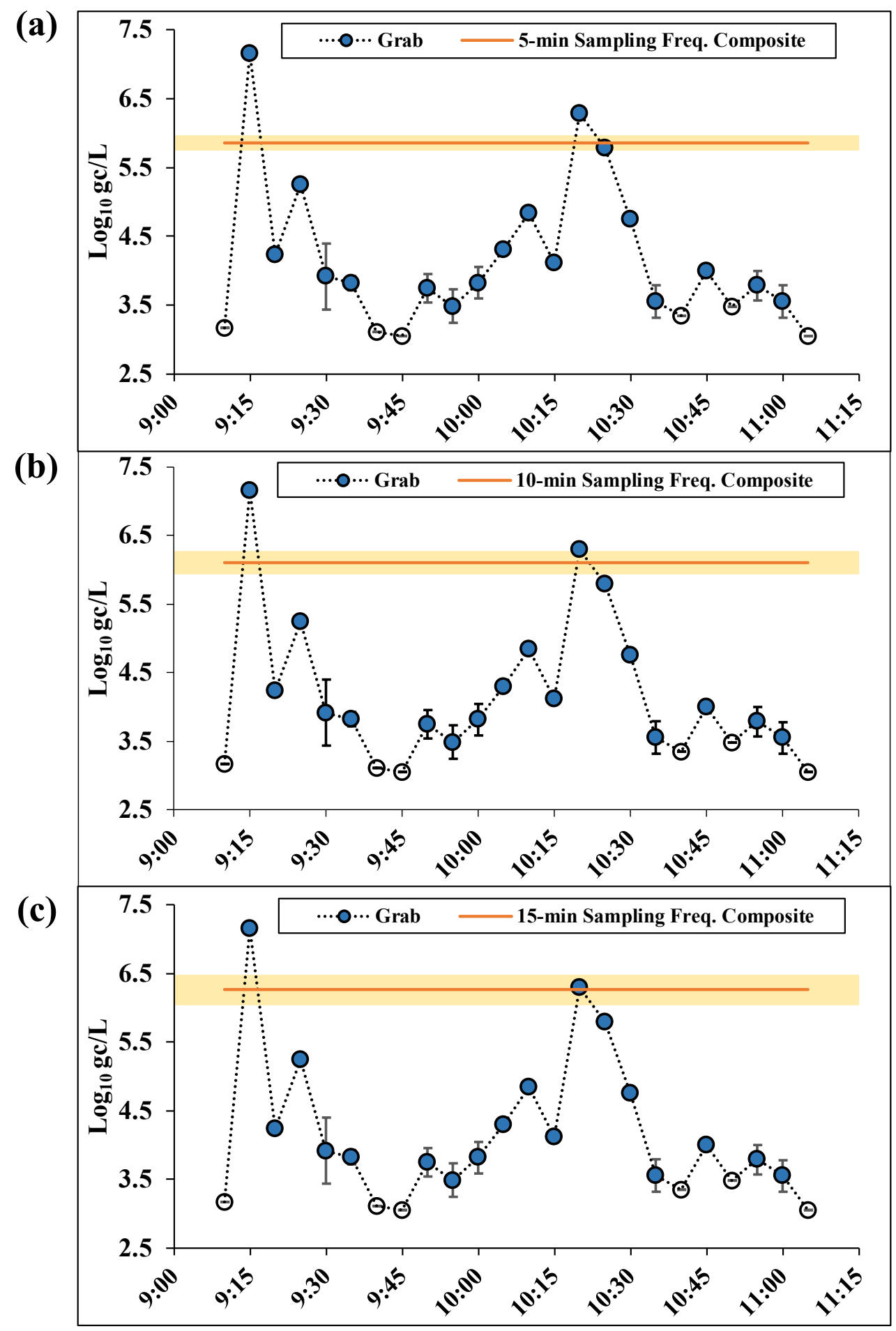

Figure S4. The 5-min grab samples collected in the first $2 \mathrm{~h}$ of sample collection plotted with a solid line indicating the (a) 5-min sampling frequency composite, (b) 10-min sampling frequency composite, and (c) 15-min sampling frequency composite. The error bars on the grab samples and the shaded range on the composite lines denote standard error. Non-detects are represented by open markers. 
(a)

(b)

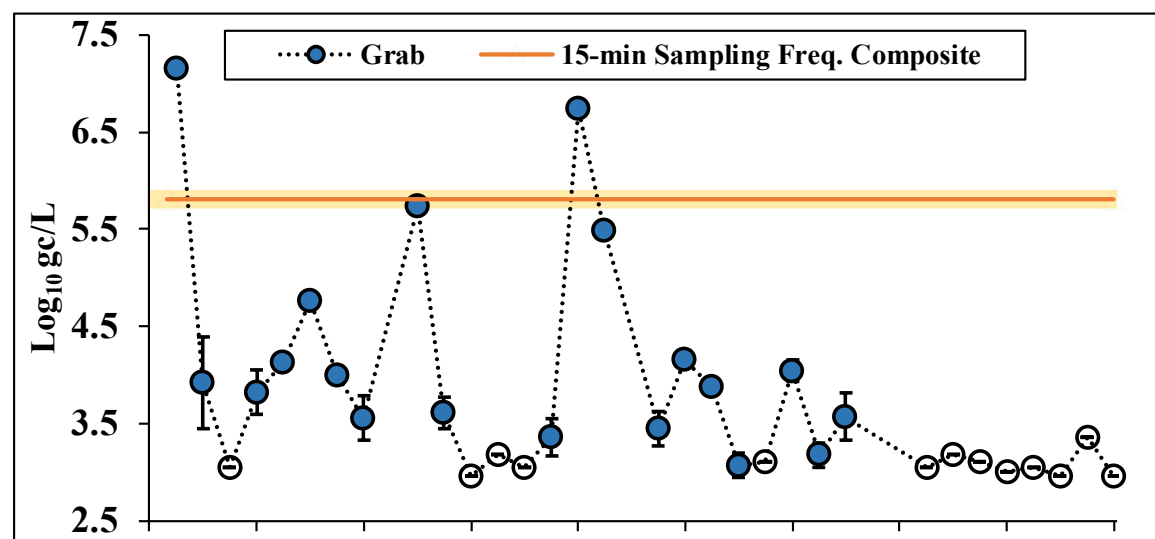

(c)

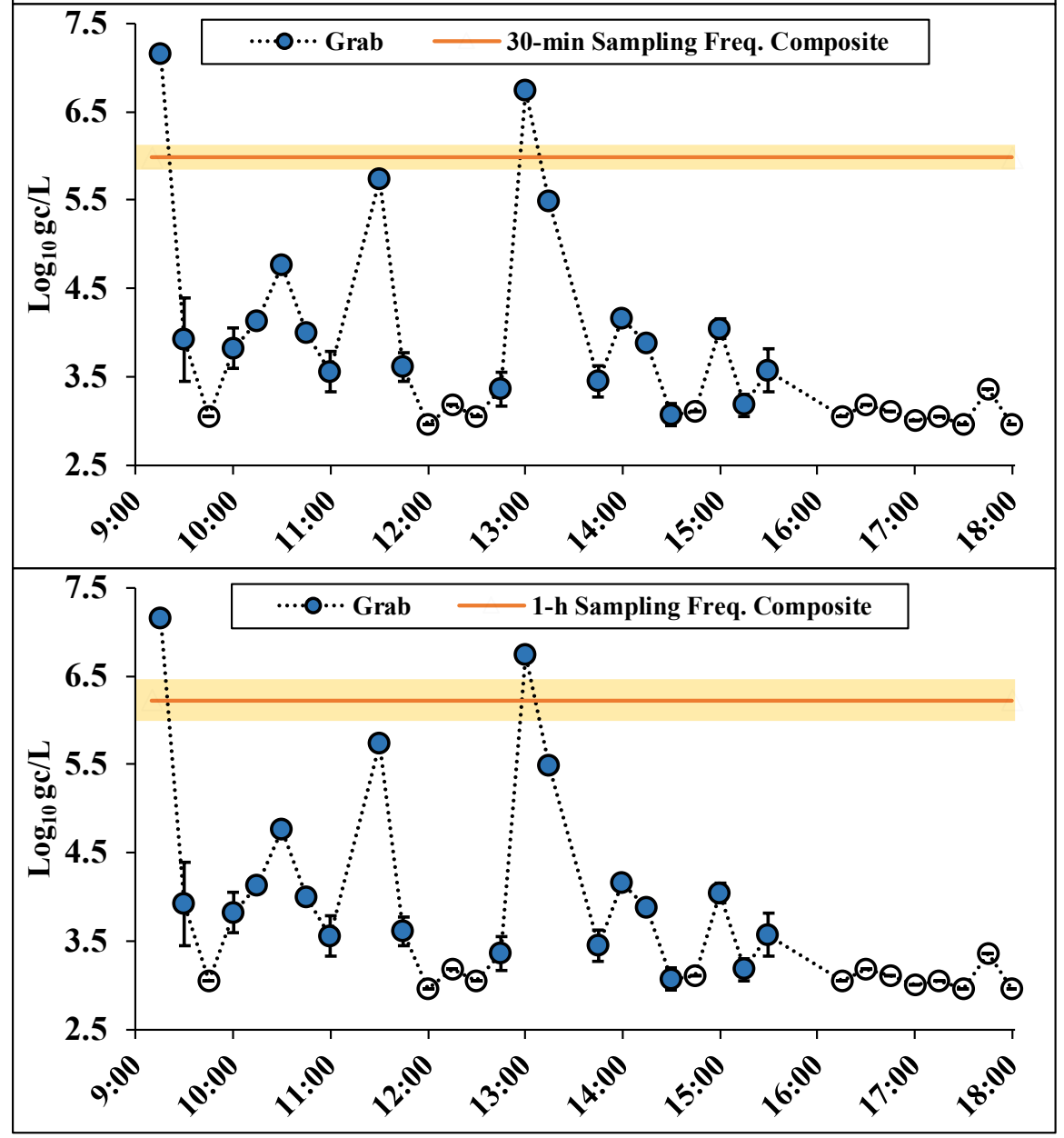

Figure S5. The 15-min grab samples collected in $8 \mathrm{~h}$ of sample collection plotted with a solid line indicating the (a) 15-min sampling frequency composite, (b) 30-min sampling frequency composite, and (c) 1-h sampling frequency composite. The error bars on the grab samples and the shaded range on the composite lines denote standard error. Non-detects are represented by open markers. 
medRxiv preprint doi: https://doi.org/10.1101/2021.07.07.21260158; this version posted July 8, 2021. The copyright holder for this preprint (which was not certified by peer review) is the author/funder, who has granted medRxiv a license to display the preprint in perpetuity.

It is made available under a CC-BY-NC-ND 4.0 International license .

Table S1. The storage time, temperature, and volume concentrated for each of the raw wastewater samples collected from the four sites.

\begin{tabular}{|c|c|c|c|c|}
\hline LOCATION & HOUR & $\begin{array}{c}\text { TEMP } \\
\text { STORED } \\
\left({ }^{\circ} \mathrm{C}\right)\end{array}$ & $\begin{array}{c}\text { DAYS } \\
\text { STORED }\end{array}$ & $\begin{array}{c}\text { VOLUME } \\
\text { FILTERED } \\
(\mathrm{mL})\end{array}$ \\
\hline Ultra-Low Flow & $9: 10$ & -20 & 50 & 30 \\
\hline Ultra-Low Flow & $9: 15$ & -20 & 9 & 30 \\
\hline Ultra-Low Flow & $9: 20$ & -20 & 50 & 35 \\
\hline Ultra-Low Flow & $9: 25$ & -20 & 50 & 10 \\
\hline Ultra-Low Flow & $9: 30$ & -20 & 9 & 30 \\
\hline Ultra-Low Flow & $9: 35$ & -20 & 50 & 50 \\
\hline Ultra-Low Flow & $9: 40$ & -20 & 50 & 35 \\
\hline Ultra-Low Flow & $9: 45$ & -20 & 9 & 40 \\
\hline Ultra-Low Flow & $9: 50$ & -20 & 50 & 30 \\
\hline Ultra-Low Flow & $9: 55$ & -20 & 50 & 35 \\
\hline Ultra-Low Flow & $10: 00$ & -20 & 9 & 30 \\
\hline Ultra-Low Flow & $10: 05$ & -20 & 50 & 30 \\
\hline Ultra-Low Flow & $10: 10$ & -20 & 50 & 40 \\
\hline Ultra-Low Flow & $10: 15$ & -20 & 9 & 30 \\
\hline Ultra-Low Flow & $10: 20$ & -20 & 50 & 10 \\
\hline Ultra-Low Flow & $10: 25$ & -20 & 50 & 30 \\
\hline Ultra-Low Flow & $10: 30$ & -20 & 9 & 30 \\
\hline Ultra-Low Flow & $10: 35$ & -20 & 50 & 30 \\
\hline Ultra-Low Flow & $10: 40$ & -20 & 50 & 20 \\
\hline Ultra-Low Flow & $10: 45$ & -20 & 9 & 35 \\
\hline Ultra-Low Flow & $10: 50$ & -20 & 50 & 15 \\
\hline Ultra-Low Flow & $10: 55$ & -20 & 50 & 30 \\
\hline Ultra-Low Flow & 11:00 & -20 & 9 & 30 \\
\hline Ultra-Low Flow & $11: 05$ & -20 & 50 & 40 \\
\hline Ultra-Low Flow & $11: 30$ & -20 & 24 & 40 \\
\hline Ultra-Low Flow & $11: 45$ & -20 & 24 & 30 \\
\hline Ultra-Low Flow & $12: 00$ & -20 & 24 & 50 \\
\hline Ultra-Low Flow & $12: 15$ & -20 & 11 & 30 \\
\hline Ultra-Low Flow & $12: 30$ & -20 & 11 & 30 \\
\hline Ultra-Low Flow & $12: 45$ & -20 & 11 & 30 \\
\hline Ultra-Low Flow & $13: 00$ & -20 & 11 & 45 \\
\hline Ultra-Low Flow & $13: 15$ & -20 & 24 & 30 \\
\hline Ultra-Low Flow & $13: 45$ & -20 & 24 & 50 \\
\hline Ultra-Low Flow & $14: 00$ & -20 & 24 & 40 \\
\hline Ultra-Low Flow & $14: 15$ & -20 & 24 & 35 \\
\hline Ultra-Low Flow & $14: 30$ & -20 & 24 & 50 \\
\hline Ultra-Low Flow & $14: 45$ & -20 & 31 & 35 \\
\hline Ultra-Low Flow & $15: 00$ & -20 & 31 & 30 \\
\hline Ultra-Low Flow & $15: 15$ & -20 & 31 & 40 \\
\hline
\end{tabular}




\begin{tabular}{|c|c|c|c|c|}
\hline Ultra-Low Flow & $15: 30$ & -20 & 31 & 30 \\
\hline Ultra-Low Flow & $16: 15$ & -20 & 31 & 40 \\
\hline Ultra-Low Flow & $16: 30$ & -20 & 31 & 30 \\
\hline Ultra-Low Flow & $16: 45$ & -20 & 31 & 35 \\
\hline Ultra-Low Flow & $17: 00$ & -20 & 31 & 45 \\
\hline Ultra-Low Flow & $17: 15$ & -20 & 31 & 40 \\
\hline Ultra-Low Flow & $17: 30$ & -20 & 31 & 50 \\
\hline Ultra-Low Flow & $17: 45$ & -20 & 31 & 20 \\
\hline Ultra-Low Flow & $18: 00$ & -20 & 31 & 50 \\
\hline Low-Flow & 1 & -20 & 12 & 40 \\
\hline Low-Flow & 2 & -20 & 12 & 40 \\
\hline Low-Flow & 3 & -20 & 12 & 30 \\
\hline Low-Flow & 4 & -20 & 12 & 30 \\
\hline Low-Flow & 5 & -20 & 12 & 35 \\
\hline Low-Flow & 6 & -20 & 12 & 40 \\
\hline Low-Flow & 7 & -20 & 12 & 25 \\
\hline Low-Flow & 8 & -20 & 12 & 40 \\
\hline Low-Flow & 9 & -20 & 12 & 40 \\
\hline Low-Flow & 10 & -20 & 12 & 40 \\
\hline Low-Flow & 11 & -20 & 12 & 40 \\
\hline Low-Flow & 12 & -20 & 12 & 45 \\
\hline Low-Flow & 13 & -20 & 12 & 50 \\
\hline Low-Flow & 14 & -20 & 12 & 50 \\
\hline Low-Flow & 15 & -20 & 12 & 50 \\
\hline Low-Flow & 16 & -20 & 12 & 50 \\
\hline Low-Flow & 17 & -20 & 12 & 40 \\
\hline Low-Flow & 18 & -20 & 12 & 50 \\
\hline Low-Flow & 19 & -20 & 12 & 40 \\
\hline Low-Flow & 20 & -20 & 12 & 40 \\
\hline Low-Flow & 21 & -20 & 12 & 40 \\
\hline Low-Flow & 22 & -20 & 12 & 40 \\
\hline Low-Flow & 23 & -20 & 12 & 30 \\
\hline Low-Flow & 24 & -20 & 12 & 40 \\
\hline Low-Flow & Composite & -20 & 12 & 40 \\
\hline Med-Flow & 1 & -20 & 15 & 20 \\
\hline Med-Flow & 2 & -20 & 15 & 20 \\
\hline Med-Flow & 3 & -20 & 15 & 20 \\
\hline Med-Flow & 4 & -20 & 15 & 20 \\
\hline Med-Flow & 5 & -20 & 15 & 20 \\
\hline Med-Flow & 7 & -20 & 15 & 10 \\
\hline Med-Flow & 8 & -20 & 15 & 30 \\
\hline Med-Flow & 9 & -20 & 15 & 20 \\
\hline Med-Flow & 10 & -20 & 15 & 30 \\
\hline Med-Flow & 11 & -20 & 15 & 30 \\
\hline Med-Flow & 12 & -20 & 15 & 30 \\
\hline
\end{tabular}




\begin{tabular}{|c|c|c|c|c|}
\hline Med-Flow & 13 & -20 & 15 & 30 \\
\hline Med-Flow & 14 & -20 & 15 & 20 \\
\hline Med-Flow & 15 & -20 & 15 & 20 \\
\hline Med-Flow & 16 & -20 & 15 & 30 \\
\hline Med-Flow & 17 & -20 & 15 & 20 \\
\hline Med-Flow & 18 & -20 & 15 & 20 \\
\hline Med-Flow & 19 & -20 & 15 & 30 \\
\hline Med-Flow & 20 & -20 & 15 & 30 \\
\hline Med-Flow & 21 & -20 & 15 & 30 \\
\hline Med-Flow & 22 & -20 & 15 & 30 \\
\hline Med-Flow & 23 & -20 & 15 & 20 \\
\hline Med-Flow & 24 & -20 & 15 & 20 \\
\hline Med-Flow & Composite & -20 & 15 & 30 \\
\hline High-Flow & 1 & -20 & 8 & 50 \\
\hline High-Flow & 2 & -20 & 8 & 50 \\
\hline High-Flow & 3 & -20 & 8 & 50 \\
\hline High-Flow & 4 & -20 & 8 & 50 \\
\hline High-Flow & 5 & -20 & 8 & 30 \\
\hline High-Flow & 6 & -20 & 8 & 50 \\
\hline High-Flow & 7 & -20 & 8 & 50 \\
\hline High-Flow & 8 & -20 & 8 & 50 \\
\hline High-Flow & 9 & -20 & 8 & 50 \\
\hline High-Flow & 10 & -20 & 8 & 50 \\
\hline High-Flow & 11 & -20 & 8 & 50 \\
\hline High-Flow & 12 & -20 & 8 & 50 \\
\hline High-Flow & 13 & -20 & 8 & 50 \\
\hline High-Flow & 14 & -20 & 8 & 50 \\
\hline High-Flow & 15 & -20 & 8 & 50 \\
\hline High-Flow & 16 & -20 & 8 & 50 \\
\hline High-Flow & 17 & -20 & 8 & 50 \\
\hline High-Flow & 18 & -20 & 8 & 50 \\
\hline High-Flow & 19 & -20 & 8 & 50 \\
\hline High-Flow & 20 & -20 & 8 & 50 \\
\hline High-Flow & 21 & -20 & 8 & 50 \\
\hline High-Flow & 22 & -20 & 8 & 50 \\
\hline High-Flow & 23 & -20 & 8 & 50 \\
\hline High-Flow & 24 & -20 & 8 & 50 \\
\hline High-Flow & Composite & -20 & 8 & 50 \\
\hline
\end{tabular}


medRxiv preprint doi: https://doi.org/10.1101/2021.07.07.21260158; this version posted July 8, 2021. The copyright holder for this preprint (which was not certified by peer review) is the author/funder, who has granted medRxiv a license to display the preprint in perpetuity. It is made available under a CC-BY-NC-ND 4.0 International license. 